\title{
Whole blood transfusion versus component therapy in adult trauma patients with acute major haemorrhage: a systematic review.
}

Pascale Avery1,2, Sarah Morton, Harriet Tucker2,4,5, Laura Green2,6,7, Anne Weaver2,8, Ross Davenport2,9

\section{Corresponding author:}

Dr. Pascale Avery BMBS MSc FHEA MRCEM

Southmead Hospital Emergency Department, Southmead Road, Bristol, BS10 5NB.

pascale.avery@nhs.net

01174144979

1. North Bristol NHS Trust, Bristol, UK

2. Blizard Institute, Queen Mary University of London, UK

3. Imperial College Healthcare NHS Trust, London, UK

4. St George's University Hospitals NHS Foundation Trust, London, UK

5. Air Ambulance Kent Surrey Sussex, UK

6. NHS Blood and Transplant, London, UK

7. Haematology Department, Barts Health NHS Trust, London, UK

8. London's Air Ambulance, The Royal London Hospital, London, UK

9. Trauma and Vascular Surgery, Barts Health NHS Trust, London, UK

Word count (excluding abstract, references, tables and figures): 2,991

\section{Acknowledgements:}

Dr. Joachim Tan, Senior Statistician, St Georges University Hospital, London, UK 


\section{ABSTRACT}

\section{Objective}

In the era of damage control resuscitation of trauma patients with acute major haemorrhage, transfusion practice has evolved to blood component (component therapy) administered in a ratio that closely approximates whole blood (WB). However, there is a paucity of evidence supporting the optimal transfusion strategy in these patients. The primary objective was therefore to establish if there is an improvement in survival at 30-days with the use of WB transfusion compared with blood component therapy in adult trauma patients with acute major haemorrhage.

\section{Methodology}

A systematic literature search was performed on the 15th December 2019 to identify studies comparing WB transfusion with component therapy in adult trauma patients and mortality at 30 days. Studies which did not report mortality were excluded. Methodological quality of included studies was interpreted using the Cochrane risk of bias tool, and rated using the Grading of Recommendations Assessment, Development and Evaluation (GRADE) approach.

\section{Results}

Search of the databases identified 1885 records, and six studies met the inclusion criteria involving 3255 patients. Of the three studies reporting 30-day mortality (one RCT (moderate evidence) and two retrospective (low and very low evidence respectively)), only one study demonstrated a statistically significant difference between WB and component therapy, and two found no statistical difference. Two retrospective studies reporting in-hospital mortality found no statistical difference in unadjusted mortality, but both reported statistically significant logistic regression analyses demonstrating that those with a WB transfusion strategy were less likely to die. 


\section{Conclusion}

Recognising the limitations of this systematic review relating to the poorquality evidence and limited number of included trials, it does not provide evidence to support or reject use of WB transfusion compared with component therapy for adult trauma patients with acute major haemorrhage.

\section{Key messages}

What is already known on this subject

- Transfusion practice in trauma has evolved to administration of blood component therapy (red cells, plasma and platelets) in a ratio that closely approximates whole blood.

- However, it has not been determined if whole blood vs. component therapy is superior.

What this study adds

- In this systematic review, we found six studies directly addressing WB vs. component therapy. Overall level of evidence was very low to moderate with only $1 \mathrm{RCT}$. No studies reported worse survival with whole blood, however, there is insufficient evidence to support or reject the use of whole blood transfusion compared with component therapy for adult trauma patients with acute major haemorrhage.

- Larger prospective, randomised or adaptive trials are required to better understand if whole blood improves survival in adult trauma patients with acute major haemorrhage compared with component therapy. 


\section{BACKGROUND}

Death from traumatic injury is a leading cause of life-years lost worldwide.(13) In 2010 there were more deaths from injuries (5.1 million) than HIV-AIDS, tuberculosis and malaria combined (3.8 million).(4) Around $40 \%$ of trauma deaths result from uncontrolled haemorrhage with the majority of patients dying within the first 24 hours after injury. $(5,6)$

Blood banks were pioneered during the First World War and fresh whole blood was the preferred product for resuscitating trauma patients in haemorrhagic shock. (7) Whole blood (WB) can be transfused fresh within 24 hours of donation, or cold-stored for up to 35 days depending on the additive solution. $(8,9)$ In military settings, fresh WB remained the primary resuscitation fluid until the 1960s when advances were made in blood component separation.(10) Blood component therapy has become the predominant transfusion approach in middle and high income countries as the extension of shelf-life provided a more manageable approach for blood services. This change in transfusion strategy occurred without evidence to compare the efficacy and risks of WB compared with component therapy in patients with acute major haemorrhage.(11) Leucoreduction techniques have since been developed with improved clinical outcomes in non-haemolytic transfusion reactions, disease transmission, and HLA alloimmunisation.(12)

Over the last ten years, damage control resuscitation principles have gained wide acceptance in civilian practice for trauma patients with acute major bleeding, based on prevention and correction of trauma-induced coagulopathy and rapid haemorrhage control. Evidence suggests that trauma-induced coagulopathy is a multifactorial failure of coagulation due to endogenous acute traumatic coagulopathy (13) and dilutional resuscitation-induced coagulopathy.(14)

The damage control resuscitation approach promotes early transfusion of red blood cells, plasma and platelets in a 1:1:1 ratio, rapid surgical control of ongoing bleeding and prevention of acidosis and hypothermia.(15-18) 
Hypotensive resuscitation is advocated until bleeding control is achieved.(19) Of note, patients with traumatic brain injury (TBI) are not generally resuscitated with permissive hypotension as they require a higher mean arterial pressure to maintain cerebral perfusion. Damage control resuscitation efforts are focused on minimising the impact of trauma-induced coagulopathy by limiting the use of crystalloid and transfusing blood component in a ratio that closely approximates WB. The United States Tactical Combat Casualty Care guidelines published in 2017 and 2018 advocate the use of WB transfusion. $(20,21)$ WB contains the individual component in a smaller transfusion volume with increased haematocrit and fibrinogen, reducing the total non-haemostatic, non-oxygen carrying fluid transfused into a trauma patient. Theoretically, use of WB may correct acute traumatic coagulopathy more efficiently than component therapy due to the simultaneous infusion of platelets and plasma with the red cells, which when administered together may reduce mortality and transfusion requirements.(22)

Despite changes in transfusion practice in trauma patients, there is a paucity of evidence to guide the optimal transfusion strategy for blood component in trauma. Recent military experience suggests that WB may be the optimum transfusion strategy; however, no systematic review has been conducted to date.(19) 


\section{METHODOLOGY}

We performed a systematic review of studies comparing WB to component therapy in adult trauma patients with acute major haemorrhage. Our primary outcome was survival at 30-days. Secondary outcomes were in-hospital mortality, 24-hour mortality, total volume of transfusion, morbidity including Acute Respiratory Distress Syndrome (ARDS), Acute Kidney Injury (AKI), Multiple Organ Dysfunction Syndrome (MODS), embolic events and transfusion reactions.

This systematic review was carried out in accordance with to the Preferred Reporting Items for Meta-Analyses (PRISMA) guidelines (23) and was prospectively entered onto the PROSPERO register (CRD42019131406).(24)

Electronic database searching was carried out in line with PRISMA guidelines. PubMed, Web of Science, Cochrane, OVID, Embase and the Transfusion Evidence Library were searched independently by two reviewers (PA and SM) using MESH terms combined with the Boolean operator 'AND' (Table 1). The search dates start from the inception of the databases to the search date (15th December 2019). Non-English language papers, abstracts and other nonpublished data were excluded; abstracts and non-published data were excluded to ensure the included literature had been peer-reviewed. 


\begin{tabular}{|l|}
\hline Terms for whole blood \\
\hline $\begin{array}{l}\text { blood OR blood transfusion OR whole blood OR whole blood transfusion OR blood } \\
\text { banks OR blood bank OR blood* }\end{array}$ \\
\hline Terms for component therapy \\
\hline $\begin{array}{l}\text { blood component transfusion OR component therapy OR blood transfusion OR } \\
\text { platelets OR plasma OR red blood cells OR red cells OR erythrocyte transfusion OR } \\
\text { packed cell OR simple cell }\end{array}$ \\
\hline Terms for haemorrhagic shock \\
\hline $\begin{array}{l}\text { exsanguination OR acute haemorrhage OR acute bleeding OR haemorrhagic shock } \\
\text { OR haemorrhage OR acute major haemorrhage OR code red }\end{array}$ \\
\hline Terms for adult \\
\hline adult \\
\hline Terms for trauma patients \\
\hline $\begin{array}{l}\text { trauma OR polytrauma OR blunt trauma OR penetrating trauma OR wounds OR } \\
\text { injuries }\end{array}$ \\
\hline $\begin{array}{l}\text { Terms for types of trials } \\
\text { MI OR AKI OR acute kidney injury OR acute renal failure OR outcome OR outcomes } \\
\text { OR thrombotic events OR immunological reactions } \\
\text { observational OR cohort studies OR RCT OR randomised* }\end{array}$ \\
\hline Terms for outcomes \\
\hline $\begin{array}{l}\text { morbidity OR mortality OR multiorgan failure OR organ failure OR sepsis OR } \\
\text { ransfusion reaction OR adult respiratory distress syndrome OR myocardial infarction }\end{array}$ \\
\hline
\end{tabular}

Table 1 Electronic database search terms combined with Boolean operator 'AND'

Titles and abstracts were uploaded to EndNote $X 7$, duplicates were removed and relevant titles were selected by two independent reviewers (PA and SM). Where indicated, full text papers were reviewed for inclusion or exclusion based on clear criteria (Table 2). Reference lists were screened for relevant titles. Authors of three included studies were contacted to clarify the time point of recorded 'mortality' and to request missing data, but no replies were received. $(8,25,26)$ For studies deemed relevant by abstract the full text report was retrieved and examined further for compliance with the inclusion criteria. There were no relevant unpublished materials or conference abstracts 
excluded because they lacked a full report, and no disagreements between the two independent reviewers about the inclusion of studies.

\begin{tabular}{|c|c|c|}
\hline & Inclusion criteria & Exclusion criteria \\
\hline $\begin{array}{l}\text { Study } \\
\text { design }\end{array}$ & $\begin{array}{l}\text { Randomised controlled trials } \\
\text { comparing the effects of whole } \\
\text { blood vs. component therapy } \\
\text { between two groups or more. } \\
\text { Prospective or retrospective } \\
\text { observational cohort studies. }\end{array}$ & $\begin{array}{l}\text { Unpublished material (PhD/MSc } \\
\text { thesis), letters to the editor, } \\
\text { reviews and conference } \\
\text { abstracts. }\end{array}$ \\
\hline Participants & $\begin{array}{l}\text { Human subjects aged } \geq 16 \text { years } \\
\text { requiring } \\
\text { uncrossmatched blood following } \\
\text { traumatic injury }\end{array}$ & $\begin{array}{l}<16 \text { years } \\
\text { Animal or cadaveric studies }\end{array}$ \\
\hline Outcome & $\begin{array}{l}\text { Reported outcomes of 30-day } \\
\text { mortality and/or in-hospital } \\
\text { mortality, 24-hour mortality, total } \\
\text { volume of units transfused, } \\
\text { morbidity including ARDS, AKI, } \\
\text { MODS, embolic events and } \\
\text { transfusion reactions. }\end{array}$ & $\begin{array}{l}\text { Mortality not reported as an } \\
\text { outcome }\end{array}$ \\
\hline Language & English language papers & Non-English language papers \\
\hline
\end{tabular}

Table 2 Inclusion and exclusion criteria

Records of each database search were kept, the date, total number of hits, number of duplicates removed, number excluded based on title, number excluded based on abstract and full text for each reviewer. All titles were stored on EndNote X7.

The two reviewers (PA and SM) extracted data independently into Excel. Extracted information included: authors, year, title, country, study design, study setting, time period, number of participants, study population, primary outcome measure, secondary outcome measures, inclusion and exclusion criteria, details of whole blood transfusion, details of component therapy, mortality at 30-day or in-hospital, mortality at 24-hour (if reported), TBI (if 
reported), and study conclusions. Information collected for risk of bias assessment for individual study methodology and reporting included: participant selection, participant and allocation concealment, handling of incomplete outcome data, and outcome reporting.

Following data extraction, percentage of 30-day or in hospital mortality was presented. Results from each study were defined as statistically significant if the $p$ value was $<0.05$. Due to the diversity between the included study populations and interventions, pooling of outcome data for meta-analysis was not performed. Findings are presented narratively.

The GRADE approach was used as a systematic method to rate the reliability of evidence from each included study.(27) As part of this, limitations of included study designs and execution were assessed using the Cochrane risk of bias tool. (28) Heterogeneity between included studies, indirectness and imprecision were assessed. Quality appraisal was carried out by both reviewers (PA and SM) independently. There were no disagreements between the reviewers regarding the risk of bias and GRADE rating. 


\section{RESULTS}

A summary of the literature search is shown in Figure 1. We screened 1551 records after duplicates were removed, and 1477 were excluded by title. 65 records were excluded by abstract and nine full texts were assessed for eligibility. Three full text articles were excluded as two were review articles, and one did not compare WB with component therapy. A total of six studies, involving 3255 patients, met the inclusion criteria. No ongoing studies or unpublished abstracts were identified at the time of search (15th December 2019).

Figure 1. Summary of literature search
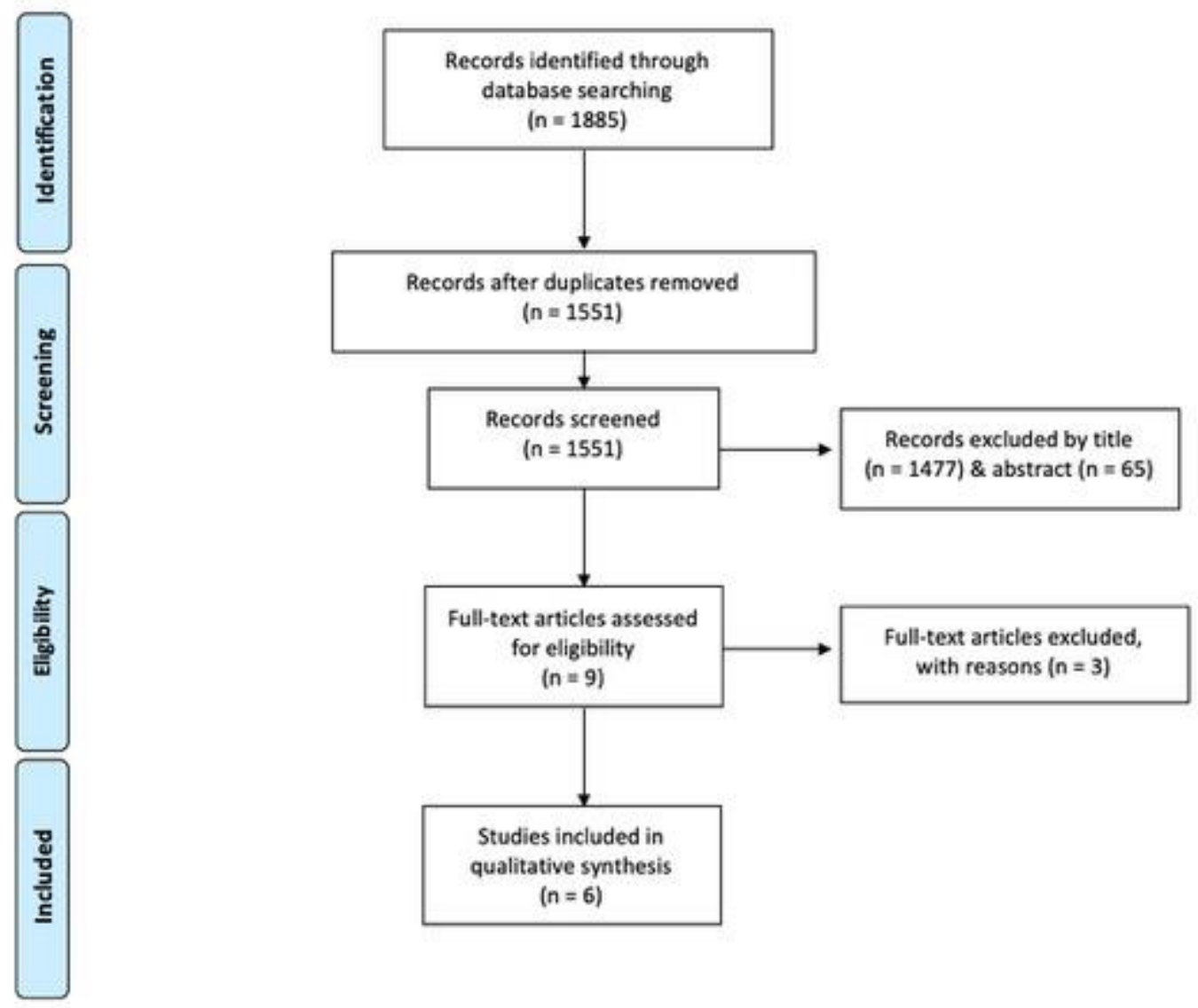


\section{Included studies}

\section{Setting}

Three studies were military based in Afghanistan and Iraq involving combat casualties (total $n=1211) .(26,29,30)$ The other three studies were conducted in the United States with civilian patients (total $n=2044) .(8,25,31)$ One civilian study included patients aged 15-91 years in their component therapy group.(8) All other included patients are $\geq 16$ years.

\section{Interventions}

The studies incorporated a wide range of transfusion strategies. Each study looked at a transfusion approach involving WB and compared this to component therapy. There was considerable variation in the definition of WB transfusion and component. For example, Cotton et al. defined their WB transfusion as leucoreduced, modified WB with the addition of apheresis platelets for every six units.(31) Another study defined the WB group as receiving non-leucoreduced, warm fresh WB with red blood cells and plasma.(30)

\section{Trial design}

Two out of the six included studies were prospective: one prospective randomised trial (31), and the other prospective with historical controls.(8) The other four studies were retrospective analyses. $(25,26,29,30)$

All six studies reported mortality, four as a primary outcome measure $(25,26$, $29,30)$, and two as a secondary outcome measure.(8, 31) 30-day and 24hour mortality was reported in three studies (29-31), with two others reporting in-hospital mortality $(25,26)$, and one reporting mortality with no further detail.(8)

Three studies reported rates of ARDS (29-31), two reported rates of AKI (30, $31)$, two reported rates of $\operatorname{MODS}(29,31)$, and two reported rates of embolic events. $(29,30)$ Transfusion volumes are reported by four studies.(8, 26, 30, 31) Three studies reported transfusion reactions. $(8,26,31)$ 


\section{Risk of bias and quality appraisal}

Risk of bias interpretation is displayed in Table 3. A summary of author judgement is presented in Figure 2.

Figure 2. Summary of risk of bias

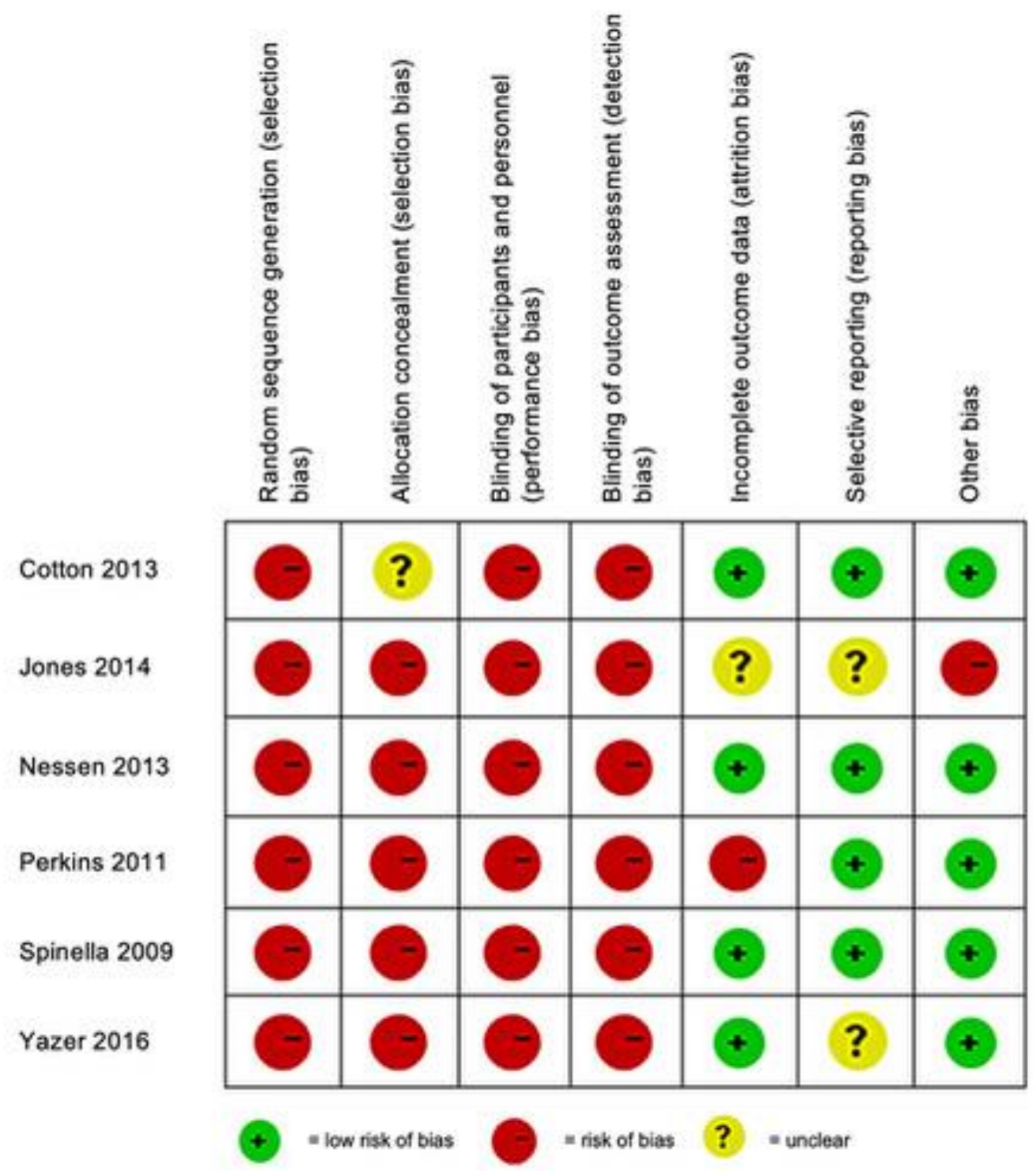

Selection bias was present in all six included studies. Four of these are retrospective with selection bias inherent in design. Selection bias was also present in the prospective, randomised trial resulted due to the lack of an objective scoring system to randomise patients.(31) Most studies reported 
efforts to minimise attrition bias. Only one paper reported significant incomplete outcome data which may bias the result (if the unknown outcomes were poorer in one group), and limits the power to detect a statistical difference.(29) Due to important differences between studies in terms of populations, interventions, designs and outcome measures, we did not pool the data for meta-analysis. 


\begin{tabular}{|c|c|c|c|c|c|}
\hline Study & Design & $\begin{array}{l}\text { Initial } \\
\text { GRADE }\end{array}$ & \multicolumn{2}{|l|}{ Risk of bias interpretation } & GRADE \\
\hline $\begin{array}{l}\text { Cotton et al } \\
\text { (31) }\end{array}$ & $\begin{array}{l}\text { Prospective, } \\
\text { Randomised trial }\end{array}$ & $\mathrm{HIGH}$ & $\begin{array}{ll}\text { HIGH}^{*} & \\
\text { - Selection bias: no objective scoring system to randomise patients } \\
\text { - Performance bias: due to inadequate concealment of allocations } \\
\text { - Detection bias: due to knowledge of the allocated interventions by outcome } \\
\text { - Study and clinical personnel unblinded to treatment group }\end{array}$ & $\begin{array}{l}\text { Serious } \\
\text { limitations, } \\
\text { downgrade one } \\
\text { level }\end{array}$ & MODERATE $\oplus \oplus \oplus$ \\
\hline $\begin{array}{l}\text { Jones et al } \\
(25)\end{array}$ & Retrospective & LOW & $\begin{array}{cl}\text { HIGH* }^{*} & \\
\text { - } & \text { Selection bias: retrospective study } \\
\text { - } & \text { Reporting bias: due to selective outcome reporting } \\
\text { - } & \text { WB not further qualified } \\
\text { - Number of products transfused not reported } \\
\text { - }\end{array}$ & $\begin{array}{l}\text { Serious } \\
\text { limitations, } \\
\text { downgrade one } \\
\text { level }\end{array}$ & VERY LOW $\oplus$ \\
\hline $\begin{array}{l}\text { Nessen et al } \\
(26)\end{array}$ & $\begin{array}{l}\text { Retrospective } \\
\text { analysis of } \\
\text { prospectively } \\
\text { collected dataset }\end{array}$ & LOW & $\begin{array}{l}\text { UNCLEAR } \\
\text { - Selection bias: retrospective convenience sample of those teams that had } \\
\text { collected data introducing sampling bias } \\
\text { - Survival bias: minimised by eliminating patients who died in first hour }\end{array}$ & $\begin{array}{l}\text { No serious } \\
\text { limitations, do not } \\
\text { downgrade }\end{array}$ & 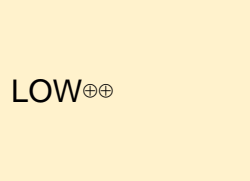 \\
\hline $\begin{array}{l}\text { Perkins et al } \\
\text { (29) }\end{array}$ & Retrospective review & LOW & $\begin{array}{ll}\mathrm{HIGH}^{*} & \\
\text { - } & \text { Selection bias: retrospective study } \\
\text { - } & \text { Attrition bias: due to amount of incomplete outcome data, huge loss to } \\
& \text { follow up } \\
\text { - } & \text { Survival bias }\end{array}$ & $\begin{array}{l}\text { Serious } \\
\text { limitations, } \\
\text { downgrade one } \\
\text { level }\end{array}$ & VERY LOW $\oplus$ \\
\hline $\begin{array}{l}\text { Spinella et al } \\
(30)\end{array}$ & Retrospective & LOW & $\begin{array}{l}\text { UNCLEAR* } \\
\text { - Selection bias: retrospective study } \\
\text { - } \quad \text { Survival bias }\end{array}$ & $\begin{array}{l}\text { No serious } \\
\text { limitations, do not } \\
\text { downgrade }\end{array}$ & LOW $\oplus \oplus$ \\
\hline $\begin{array}{l}\text { Yazer et al } \\
(8)\end{array}$ & $\begin{array}{l}\text { Prospective, historical } \\
\text { controls }\end{array}$ & LOW & $\begin{array}{cl}\mathrm{HIGH}^{*} & \\
\text { - Selection bias: groups produced not directly comparable, significance } \\
\\
\text { difference in median age of patients, biased allocation to intervention }\end{array}$ & $\begin{array}{l}\text { Serious } \\
\text { limitations, } \\
\text { downgrade one } \\
\text { level }\end{array}$ & VERY LOW $\oplus$ \\
\hline
\end{tabular}

Table 3 Quality of evidence: GRADE rating with Cochrane risk of bias interpretation

* HIGH: Plausible bias that seriously weakens confidence in the results. Crucial limitation for one criterion, or some limitations for multiple criteria, sufficient to lower confidence in the estimate of effect.

** UNCLEAR: Plausible bias that raises some doubt about the results. 
Effects of interventions (see Table 4)

Primary outcome

30-day mortality is the primary outcome of this systematic review, and three studies reported this data $(n=830)$. Two studies, an RCT by Cotton et al (grade of evidence Moderate), and retrospective study by Perkins et al (grade of evidence Very Low), found no statistically significant difference in 30-day mortality between whole blood transfusion strategy and blood component therapy. $(29,31)$ The third study, a retrospective study by Spinella et al (Grade of evidence Low) found a statistically significant difference in 30-day mortality between whole blood transfusion and component therapy (5\% vs $18 \%$ respectively, $p=0.002)$.(30)

\section{Secondary outcomes}

In-hospital mortality

Two retrospective studies (Grade of evidence Very Low and Low) reported inhospital mortality and found no statistical difference in unadjusted mortality between groups $(n=2233) .(25,26)$ However, logistic regression analyses of these studies found a statistically lower likelihood of death in patients receiving whole blood transfusion strategy (see Table 4). A prospective study with historical controls (Grade of evidence Low) reported 'mortality', but did not specify a measured time point, and showed no statistically significant difference between the two groups $(n=192)$.(8)

\section{Twenty-four-hour mortality}

Three studies reported 24-hour mortality $(n=830)$. Two studies found no statistically significant difference in 24-hour mortality between whole blood transfusion strategy and blood component therapy.(29, 31); the grade of evidence for these studies was Very Low (retrospective study) and Moderate (RCT). A third, retrospective study ( $n=354$, Grade of evidence very low)) found a statistically significant difference in 24-hour mortality between whole blood transfusion and blood component therapy (4\% vs $12 \%$ respectively, $p=0.018)$.(30) 
ARDS

Three studies reported rates of ARDS. Two studies found no statistically significant difference between the two groups $(30,31)$, and one study found a higher incidence of ARDS in the fresh WB group compared to apheresis platelets (aPLT) group (18.8\% vs $7.4 \%$ respectively, $p=0.002$ ).(29)

\section{Acute Kidney Injury}

Two studies reported the incidence of AKI. One study found no statistical difference in $A K I$ between those receiving WB and those receiving component therapy.(31) One study reported a higher incidence of AKI in the group receiving WB transfusion compared to component therapy ( $8 \%$ vs $3 \%$ respectively, $p=0.04)$.(30)

\section{Multiple Organ Dysfunction Syndrome}

Two studies reported rates of MODS. Neither study found a statistically significant difference in MODS between those receiving WB transfusion and those receiving component therapy. $(29,31)$

\section{Embolic events}

Two studies reported rates of embolic events. Neither study found a statistically significant difference in embolic events between those receiving WB transfusion and those receiving component therapy. $(29,30)$

\section{Number of units transfused}

Four studies reported volume of units transfused. Two studies found no statistical difference between the number of blood products received by each group. $(8,31)$ One study reported that actual blood volume transfused was higher in component therapy group compared to the WB group $(6.8 \mathrm{~L}$ vs $5.7 \mathrm{~L}$ respectively, $p=0.03$ ).(30) One study found that FWB patients received significantly more units of both red blood cells and fresh frozen plasma.(26)

\section{Transfusion reactions}

Three studies reported on transfusion reactions. Two studies reported no transfusion reactions in patients receiving WB transfusion. $(8,26)$ One study 
reported specifically no cases of transfusion-related acute lung injury in either group.(31)

Sub-analysis of patients with TBI

Only one study excluded patients with penetrating head injury and Glasgow Coma Score of $\leq 7$.(26) One study performed a sensitivity analysis to assess outcomes of patients without severe TBI.(31) The authors found that WB significantly reduced transfusion volumes in patients without severe TBI, but there was no statistically significant difference in 30-day mortality $6 \%$ WB vs $9 \%$ component therapy, $p=0.62$ ). This again may represent a type II error as the study was not powered to demonstrate a difference in 30-day mortality. Another study we examined conducted a post-hoc analysis excluding patients with TBI, and also found that use of WB significantly reduced the number of red blood cell and platelet transfusions.(8) 


\begin{tabular}{|c|c|c|c|c|c|c|c|}
\hline Study & $\begin{array}{l}\text { Number of } \\
\text { participants }\end{array}$ & $\begin{array}{l}\text { Inclusion } \\
\text { criteria }\end{array}$ & Outcome measures & Whole Blood & $\begin{array}{c}\text { Component } \\
\text { Therapy }\end{array}$ & Results & $\begin{array}{l}\text { Quality of the } \\
\text { evidence } \\
\text { (GRADE) }\end{array}$ \\
\hline $\begin{array}{l}\text { Cotton et } \\
\text { al. (2013) } \\
\text { (31) }\end{array}$ & 107 & $\begin{array}{l}>18 \text { years old, } \\
\text { highest level } \\
\text { trauma activation, } \\
\text { active bleeding } \\
\text { requiring uncross } \\
\text { matched blood }\end{array}$ & $\begin{array}{l}\text { Primary: } 24 \mathrm{~h} \text { blood product } \\
\text { use } \\
\text { Secondary: } 24 \mathrm{~h} \text { mortality, } \\
\text { 30d mortality, length of stay, } \\
\text { transfusion associated } \\
\text { complications, infections }\end{array}$ & $\begin{array}{c}\text { mWB } \\
\text { (leucoreduced) } \\
+ \text { aPLT for every } \\
6 \text { units }\end{array}$ & $\begin{array}{l}\text { RBC + plasma } \\
+ \text { aPLT for } \\
\text { every } 6 \text { units }\end{array}$ & $\begin{array}{l}\text { No statistical difference in 30-day mortality } \\
22 \% \text { mWB vs } 14 \% \text { BCT ( } p=0.26) \\
\text { No statistical difference in } 24 \text {-hour mortality } \\
11 \% \text { mWB vs } 10 \% \text { BCT ( } p=0.83) \\
\text { No statistical difference in } 24 \text {-hour component use } \\
\text { ( } p=0.462) \\
\text { No other statistical differences between groups in } \\
\text { ARDS, AKI, MODS }\end{array}$ & MODERATE $\oplus \oplus \oplus$ \\
\hline $\begin{array}{l}\text { Perkins et } \\
\text { al. (2011) } \\
\text { (29) }\end{array}$ & 369 & $\begin{array}{l}\text { Trauma patients } \\
\text { who required } \geq 10 \\
\text { units of blood } \\
\text { component } \\
\text { transfused within } \\
\text { first } 24 \text { hours and } \\
\text { did not receive } \\
\text { both FWB and } \\
\text { aPLT }\end{array}$ & $\begin{array}{l}\text { Primary: Survival at } \mathbf{2 4 h} \text { and } \\
\text { 30d } \\
\text { Secondary: Rates of ARDS, } \\
\text { MODS, infection, embolic } \\
\text { events }\end{array}$ & $\begin{array}{c}\text { FWB (non- } \\
\text { leucoreduced) } \\
+ \text { RBC + FFP + } \\
\text { cryo }\end{array}$ & $\begin{array}{c}\mathrm{aPLT}+\mathrm{RBC}+ \\
\mathrm{FFP}+\text { cryo }\end{array}$ & 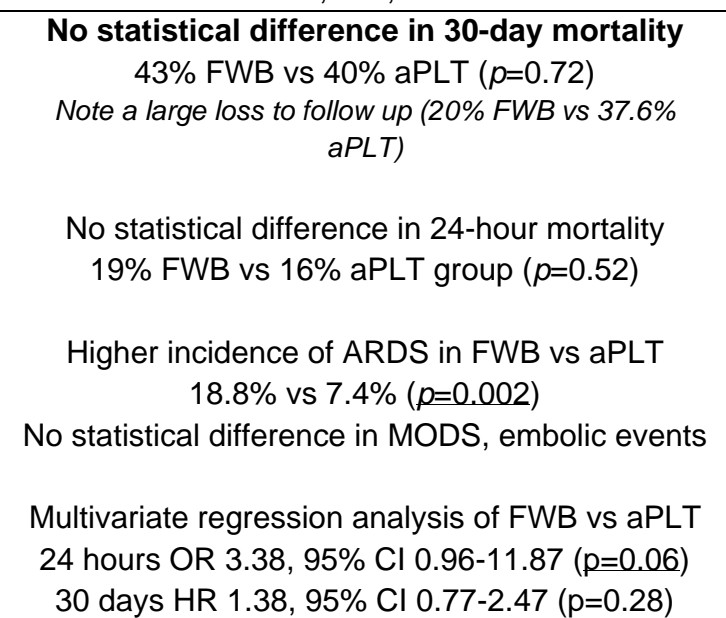 & $\underset{\oplus}{\text { VERY LOW }}$ \\
\hline $\begin{array}{l}\text { Spinella } \\
\text { et al. } \\
\text { (2009) } \\
\text { (30) }\end{array}$ & 354 & $\begin{array}{l}\text { Military combat } \\
\text { patients in } \\
\text { Afghanistan and } \\
\text { Iraq who received } \\
\text { at least } 1 \text { unit RBC } \\
\text { and were treated } \\
\text { at a level II or level } \\
\text { III hospital. Those } \\
\text { receiving both } \\
\text { WFWB and aPLT } \\
\text { were excluded. }\end{array}$ & $\begin{array}{l}\text { Primary: Survival at } 24 \mathrm{hr} \text { and } \\
\text { 30d } \\
\text { Secondary: Blood product } \\
\text { administration, adverse effects }\end{array}$ & $\begin{array}{l}\text { WFWB (non- } \\
\text { leucoreduced) } \\
+ \text { RBC + plasma }\end{array}$ & $\begin{array}{c}\mathrm{aPLT}+\mathrm{RBC}+ \\
\text { plasma }\end{array}$ & $\begin{array}{c}\text { Statistically significant difference for both 24- } \\
\text { hour and 30-day mortality } \\
\text { 24-hour: WB } 4 \% \text { vs BCT } 12 \%(p=0.018) \\
\text { 30-day: WB } 5 \% \text { vs BCT } 18 \%(p=0.002) \\
\text { Multivariate logistic regression analysis } \\
\text { improved 30-day survival in WFWB group vs BCT } \\
\text { group OR 12.4, } 95 \% \text { Cl 1.8-80 ( } p=0.01) \text {. } \\
\text { Increased AKI in WB (8\%) vs BCT group (3\%) } \\
(p=0.04) \text {. } \\
\text { No statistical difference in ARDS or embolic } \\
\text { events } \\
\text { Actual blood volume transfused higher in BCT } \\
\text { group (5.7L vs } 6.8 \mathrm{~L}, p=0.03)\end{array}$ & $\underset{\oplus \oplus}{\operatorname{LOW}}$ \\
\hline
\end{tabular}




\begin{tabular}{|c|c|c|c|c|c|c|c|}
\hline $\begin{array}{l}\text { Jones et } \\
\text { al. (2014) } \\
\text { (25) }\end{array}$ & 1745 & $\begin{array}{l}\text { Age } 18-45, \\
\text { ISS }>25 \text {, required } \\
\text { hospital } \\
\text { admission, } \\
\text { received blood } \\
\text { transfusion }\end{array}$ & $\begin{array}{l}\text { Primary: In-hospital Mortality } \\
\text { Secondary: Survival odds } \\
\text { ratios }\end{array}$ & $\begin{array}{c}\text { WB } \\
\text { (no additional } \\
\text { information } \\
\text { available) }\end{array}$ & $\mathrm{RBC}+\mathrm{PLT}$ & $\begin{array}{c}\text { No statistical difference in mortality } \\
21 \% \text { WB vs } 26 \% \text { BCT }(p=0.27) \\
\text { Logistic regression analysis } \\
\text { WB } \\
\text { BCT patients } 3.2 \text { times more likely to die vs } \\
\text { OR } 3.164,95 \% \text { Cl: } 1.314-7.618(p=0.01)\end{array}$ & $\underset{\oplus}{\text { VERY LOW }}$ \\
\hline $\begin{array}{l}\text { Nessen } \\
\text { et al. } \\
\text { (2013) } \\
\text { (26) }\end{array}$ & 488 & $\begin{array}{l}\text { Military combat } \\
\text { patients in } \\
\text { Afghanistan } \\
\text { requiring treatment } \\
\text { by the six studied } \\
\text { US Forward } \\
\text { Surgical Teams }\end{array}$ & $\begin{array}{l}\text { Primary: Mortality } \\
\text { determined at inpatient } \\
\text { discharge }\end{array}$ & $\begin{array}{c}\mathrm{FWB} \\
+\mathrm{RBC}+\mathrm{FFP}\end{array}$ & $\mathrm{RBC}+\mathrm{FFP}$ & $\begin{array}{c}\text { No statistical difference for unadjusted in- } \\
\text { hospital mortality between FWB }(5.3 \%) \& \text { BCT } \\
(8.8 \%) \text { ( } p \text { value not reported) } \\
\text { FWB were less likely to die vs BCT } \\
\text { continuous variable logistic regression analysis } \\
\text { OR } 0.096,95 \% \mathrm{Cl} 0.02-0.53 \text { ( }(=0.008) \\
\text { stratified propensity score analysis } \\
\text { OR } 0.11,95 \% \mathrm{Cl} 0.02-0.78 \text { ( } p=0.03) \\
\text { FWB patients received significantly more units of } \\
\text { RBC (12.7 vs } 4.7, p=<0.001) \text { and FFP (10 vs } 2.6 \text {, } \\
p=<0.001) \\
\text { FWB patients were more likely to receive MBT } \\
(52.1 \% \text { vs } 11.6 \%, p=<0.001) \\
\text { No statistical difference in those who received } \\
\text { type specific FWB or uncrossmatched FWB }\end{array}$ & $\underset{\oplus \oplus}{\text { LOW }}$ \\
\hline $\begin{array}{l}\text { Yazer et } \\
\text { al. (2016) } \\
\text { (8) }\end{array}$ & 192 & $\begin{array}{l}\text { Male patients } \\
\text { attending a level } 1 \\
\text { trauma centre with } \\
\text { hypotension } \\
\text { secondary to } \\
\text { bleeding who } \\
\text { received at least } \\
\text { one unit of WB } \\
\text { compared to } \\
\text { historical controls }\end{array}$ & $\begin{array}{l}\text { Primary: Haemolysis } \\
\text { (haptoglobin used as marker) } \\
\text { and transfusion reactions } \\
\text { Secondary: Transfusion } \\
\text { volumes, mortality rates (no } \\
\text { additional information available) }\end{array}$ & $\begin{array}{l}\text { WB } \\
\text { (up to } 2 \text { unit, } \\
\text { leukoreduced) } \\
+ \text { RBC + plasma } \\
+ \text { + PLT + cryo }\end{array}$ & $\begin{array}{l}\text { RBC + plasma } \\
+ \text { PLT + cryo }\end{array}$ & $\begin{array}{l}\text { No statistical difference in mortality between } \\
\text { the groups (WB } 36 \% \text { vs BCT } 28 \%, p=0.27 \text { ) } \\
\text { No statistical difference between the number of } \\
\text { blood products received by each group } \\
\text { Median haptoglobin concentration on post-WB } \\
\text { transfusion day } 1 \text { was } 25.1 \mathrm{mg} / \mathrm{dL} \text { (normal) } \\
\text { No transfusion reactions in the WB group }\end{array}$ & $\underset{\oplus}{\text { VERY LOW }}$ \\
\hline
\end{tabular}

Table 4 Summary of findings

$(B C T=$ blood component therapy; $m W B=$ modified whole blood; $W B=$ whole blood; $F W B=$ fresh whole blood; $W F W B=$ warm fresh whole blood; aPLT = apheresis platelets; $R B C=$ red blood cells; FFP = fresh frozen plasma; cryo = cryoprecipitate; ISS = injury severity score; $h r=$ hours; $d=$ days; $A R D S=$ acute respiratory distress syndrome; $A K I=$ acute kidney injury; $M O D S=$ multiple organ dysfunction syndrome; $M B T=$ massive blood transfusion $\geq 10$ units) 


\section{DISCUSSION}

This systematic review evaluated current evidence comparing whole blood transfusion with component therapy in adult trauma patients with acute major haemorrhage. There were only six studies, and overall quality was low. Of the three studies reporting our primary outcome of 30-day mortality (total of 830 patients) two had ratings for GRADE of Evidence of low and very low.(29, 30) The highest quality evidence for this outcome was an RCT (GRADE of evidence moderate) which demonstrated no statistical difference in 30-day mortality; however this study $(n=107)$ was not powered to demonstrate a difference in 30-day mortality as the primary outcome.(31) Two observational studies reporting in-hospital mortality (2233 patients) found in logistic regression analyses that patients receiving WB transfusion strategy were less likely to die. $(25,26)$ However, both studies suffered from poor quality evidence with GRADE rated low and very low.

In the studies conducted in military settings it is reported to take 30-45 minutes to receive the first unit of WB, introducing survival bias favouring the patient group receiving WB. Rapidly exsanguinating patients may not survive long enough to receive WB. Only one study attempted to minimise this bias by excluding patients who died within the first hour of treatment.(26) It is important to note this issue will not be resolved with more retrospective studies.

With WB not currently available in most civilian Western institutions, clinicians have adapted to the use of available component therapy. Interestingly, this practice now resembles reconstituted WB with component therapy transfused in a ratio of 1:1:1, after a multicentre observational study reported a reduction in mortality with higher plasma and platelet ratios (32). This was followed by an RCT demonstrating a trend toward survival in the group receiving 1:1:1 regimen compared to 1:1:2.(16) A recent secondary analysis of a multicentre randomised phase III trial reported combined red blood cells and plasma transfusion had the greatest statistical reduction in 30-day mortality (HR 0.28 , $p=<0.001$ ), compared to plasma or red blood cells or crystalloid alone 
resuscitation.(18) It should however be noted that even between trauma centres there is a significant variation in practice and the regimen used.(33)

Looking at adverse events between groups, one study $(n=354)$ reported a higher incidence of AKI in the WB group compared with component therapy.(30) Another study ( $n=369$ ) found a higher incidence of ARDS in the FWB group compared to aPLT group.(29) Neither study was designed to address these measures as their primary outcome, and therefore may not be powered to demonstrate an accurate difference. Both studies used nonleucoreduced fresh WB. Both AKI and ARDS may be the result of complex immunologic mechanisms. A simplified explanation includes inflammation caused by the transfusion of donor white blood cells.(30) White blood cells cause inflammation resulting from microvascular damage to the endothelium. In the lungs, this may cause vascular leakage into the alveolar space, resulting in pulmonary oedema and ARDS. Of note, most WB in the developing world is leucoreduced due to risk of infectious diseases such as variant Creutzfeldt-Jakob disease.

The resuscitation end points for patients with TBI differ quite significantly from those with acute major haemorrhage. Patients with TBI require a higher mean arterial pressure to maintain cerebral perfusion pressure and are not generally resuscitated with all damage control resuscitation principles including permissive hypotension. The sub-analysis of patients with TBI suggests that if TBI patients are excluded from analysis due to the differing resuscitation goals, there is trend towards whole blood significantly reducing the transfusion volumes required.(31) However, due to the studies not being powered sufficiently this is an area that requires further research.

Around a quarter to third of trauma patients requiring transfusion are coagulopathic at presentation. $(13,34)$ Presence of trauma-induced coagulopathy is an independent predictor of mortality.(35) WB is a more concentrated transfusion, reducing the total dilutional, non-haemostatic fluid transfused into a trauma patient. Therefore, WB may be superior compared to component therapy for reversing the effects of trauma-induced coagulopathy. 
Whilst fresh WB transfusion is becoming increasingly established in the military setting, there are significant practical limitations to its application in the civilian healthcare system. The mobilisation of donors and collection is resource intensive, safety testing is time consuming, and most importantly fresh WB has a short shelf-life of up to 72 hours.(36) However there are 19 trauma centres using WB in the United States (37), and civilian use of WB in the context of trauma and massive transfusion is being studied.(38-40)

\section{Limitations}

The quality of this systematic review is limited by methodology of the studies it appraises. The papers were mostly retrospective cohort studies with one prospective randomised trial. There was a paucity of high quality evidence. This systematic review is also limited by the significant heterogeneity of included studies. Both intervention and control groups are not consistent across studies. For example, one study compared leucoreduced mWB (no native platelet function), with the addition of 1 pool of apheresis platelets for every 6 units of mWB.(31) Another used non-leucoreduced WFWB with red blood cells and plasma.(30) These differences in transfusion protocol, comparison groups and outcome measures across studies meant that data pooling and meta-analysis were not possible.

\section{CONCLUSION}

Overall this systematic review is unable to determine if the use of WB transfusion compared with component therapy improves survival at 30-days in adult trauma patients with acute major haemorrhage based on the evidence identified. However, no reduction in survival was reported with WB transfusion in any of the included studies. Larger prospective, randomised or adaptive trials are required to better understand if WB improves survival. If the use of WB is shown to be superior to component therapy, blood services are more likely to manufacture WB despite the shorter shelf life.

\section{There were no sources of funding for this systematic review.}




\section{Competing Interests Statement:}

The authors have NO affiliations with or involvement in any organisation or entity with any financial interest or non-financial interest in the subject matter discussed in this manuscript.

\section{Contributorship:}

PA responsible for study planning, first reviewer, lead author and overall content. SM second reviewer and editing. HT, LG, AW provided content advice and edited drafts. RD study supervisor, responsible for planning and conduct, responsible for overall content. Each author has been involved in the development of the final material. 


\section{REFERENCES}

1. Peden M, McGee K, Krug E, editors. Injury: a leading cause of the global burden of disease, 2000. World Health Organisation [Internet]. 2002 [accessed 2019 June 05]. Available from URL:

https://www.who.int/violence_injury_prevention/publications/other_injury/injury len/.

2. Lopez AD, Mathers CD, Ezzati M, et al. Global and regional burden of disease and risk factors, 2001: systematic analysis of population health data. Lancet. 2006; 367(9524):1747-57.

3. World Health Organisation. World Health Statistics 2010: Causespecific mortality and morbidity 2010 (p59-71) [Internet]. 2010 [accessed 2019 June 05]. Available from: http://www.who.int/whosis/whostat/EN_WHS10_Full.pdf.

4. Lozano R, Naghavi M, Foreman K, et al. Global and regional mortality from 235 causes of death for 20 age groups in 1990 and 2010: a systematic analysis for the Global Burden of Disease Study 2010. Lancet. 2012; 380(9859):2095-128.

5. Demetriades D, Murray J, Charalambides K, et al. Trauma fatalities: time and location of hospital deaths. J Am Coll Surg. 2004; 198(1):20-6. 6. Cripps MW, Kutcher ME, Daley A, et al. Cause and timing of death in massively transfused trauma patients. J Trauma Acute Care Surg. 2013; 75(Suppl 2):255-62.

7. Hedley-Whyte J, Milamed DR. Blood and war. Ulster Med J. 2010; 79(3):125-34.

8. Yazer MH, Jackson B, Sperry JL, et al. Initial safety and feasibility of cold-stored uncrossmatched whole blood transfusion in civilian trauma patients. J Trauma Acute Care Surg. 2016; 81(1):21-6.

9. Kristoffersen EK, Apelseth TO. Platelet functionality in cold-stored whole blood. International Society of Blood Transfusion. 2019; 14(3):308-14. 10. Basu D, Kulkarni R. Overview of blood components and their preparation. Indian J Anaesth. 2014; 58(5):529-37. 
11. Zielinski MD, Jenkins DH, Hughes JD, et al. Back to the future: the renaissance of whole-blood transfusions for massively hemorrhaging patients. Surgery. 2014; 155(5):883-6.

12. Blajchman MA. The clinical benefits of the leukoreduction of blood products. J Trauma. 2006;60(6 Suppl):S83-90.

13. Brohi K, Singh J, Heron M, et al. Acute traumatic coagulopathy. J Trauma. 2003; 54(6):1127-30.

14. Hess JR, Brohi K, Dutton RP, et al. The coagulopathy of trauma: a review of mechanisms. J Trauma. 2008; 65(4):748-54.

15. Beekley AC. Damage control resuscitation: a sensible approach to the exsanguinating surgical patient. Crit Care Med. 2008; 36(Suppl 7):267-74.

16. Holcomb JB, Tilley BC, Baraniuk S, et al. Transfusion of plasma, platelets, and red blood cells in a 1:1:1 vs a 1:1:2 ratio and mortality in patients with severe trauma: the PROPPR randomized clinical trial. JAMA. 2015; 313(5):471-82.

17. Sperry JL, Guyette FX, Brown JB, et al. Prehospital plasma during air medical transport in trauma patients at risk for hemorrhagic shock. $\mathrm{N}$ Engl $\mathrm{J}$ Med. 2018; 379(4):315-26.

18. Guyette FX, Sperry JL, Peitzman AB, et al. Prehospital blood product and crystalloid resuscitation in the severely injured patient: a secondary analysis of the prehospital air medical plasma trial. Ann Surg [Epub ahead of print]. 2019 [accessed 2019 June 05]. Available from URL:

https://www.ncbi.nlm.nih.gov/pubmed/30998533.

19. Cap AP, Pidcoke HF, Spinella P, et al. Damage Control Resuscitation. Military medicine. 2018; 183(Suppl 2):36-43.

20. Butler FK Jr. Fluid Resuscitation in Tactical Combat Casualty Care: Yesterday and Today. Wilderness Environ Med. 2017; 28(2S):S74-S81.

21. Butler FK Jr, Holcomb JB, Shackelford S, et al. Advanced Resuscitative Care in Tactical Combat Casualty Care: TCCC Guidelines Change 18-01:14 October 2018. J Spec Oper Med. 2018; 18(4):37-55. 22. Spinella PC, Perkins JG, Grathwohl KW, et al. Risks associated with fresh whole blood and red blood cell transfusions in a combat support hospital. Crit Care Med. 2007; 35(11):2576-81. 
23. Moher D, Liberati A, Tetzlaff J, et al. Preferred reporting items for systematic reviews and meta-analyses: the PRISMA statement. PLoS Med. 2009; 6(7):e1000097.

24. University of York. PROSPERO: International prospective register of systematic reviews [Internet]. [accessed 2019 June 05]. Available from URL: https://www.crd.york.ac.uk/prospero/.

25. Jones AR, Frazier SK. Increased mortality in adult patients with trauma transfused with blood components compared with whole blood. Journal of Trauma Nursing. 2014; 21(1):22-9.

26. Nessen SC, Eastridge BJ, Cronk D, et al. Fresh whole blood use by forward surgical teams in Afghanistan is associated with improved survival compared to component therapy without platelets. Transfusion. 2013; 53(Suppl 1):107-13.

27. Schünemann H BJ, Guyatt G, Oxman A, editors. GRADE handbook for grading quality of evidence and strength of recommendations [Internet]. Updated 2013 [accessed 2019 June 05]. Available from URL: https://gdt.gradepro.org/app/handbook/handbook.html.

28. Higgins JPT, Green S (editors). Cochrane Handbook for Systematic Reviews of Interventions Version 5.1.0 [Internet]. The Cochrane Collaboration, updated 2011 [accessed 2019 June 05]. Available from URL: www.handbook.cochrane.org.

29. Perkins JG, Cap AP, Spinella PC, et al. Comparison of platelet transfusion as fresh whole blood versus apheresis platelets for massively transfused combat trauma patients (CME). Transfusion. 2011; 51(2):242-52. 30. Spinella PC, Perkins JG, Grathwohl KW, et al. Warm fresh whole blood is independently associated with improved survival for patients with combatrelated traumatic injuries. J Trauma. 2009; 66(Suppl 4):69-76.

31. Cotton B, Podbielski J, Camp E, et al. A randomized controlled pilot trial of modified whole blood versus component therapy in severely injured patients requiring large volume transfusions. Annals of surgery. 2013; 258(4):527-32.

32. Holcomb JB, del Junco DJ, Fox EE, et al. The prospective, observational, multicenter, major trauma transfusion (PROMMTT) study: 
comparative effectiveness of a time-varying treatment with competing risks. JAMA Surg. 2013; 148(2):127-36.

33. Rijnhout TWH, Noorman F, Bek A, Zoodsma M, Hoencamp R. Massive transfusion in The Netherlands. Emerg Med J. 2020; 37(2):65-72.

34. Maegele M, Lefering R, Yucel N, et al. Early coagulopathy in multiple injury: an analysis from the German Trauma Registry on 8724 patients. Injury. 2007; 38(3):298-304.

35. MacLeod JB, Lynn M, McKenney MG, et al. Early coagulopathy predicts mortality in trauma. J Trauma. 2003; 55(1):39-44.

36. Hughes JD, Macdonald VW, Hess JR. Warm storage of whole blood for 72 hours. Transfusion. 2007; 47(11):2050-6.

37. Holcomb JB, Jenkins DH. Get ready: whole blood is back and it's good for patients. Transfusion. 2018; 58(8):1821-3.

38. Flint AWJ, McQuilten ZK, Wood EM. Massive transfusions for critical bleeding: is everything old new again? Transfus Med. 2018; 28(2):140-149. 39. Stubbs JR, Zielinski MD, Jenkins D. The state of the science of whole blood: lessons learned at Mayo Clinic. Transfusion. 2016; 56(Suppl 2):173-81. 40. Queen Mary University of London. New blood product for London's critically injured [Internet]. 2018 [accessed 2019 June 05]. Available from URL: https://www.qmul.ac.uk/media/news/2018/smd/new-blood-product-forlondons-critically-injured.html. 